\title{
THE METHODOLOGY TO SYSTEMATISE, PRESENT AND USE HISTORICAL CARTOGRAPHY: POTENTIALS AND LIMITS TO ANALYSE AND ENHANCE WIDESPREAD HISTORICAL CENTRES IN NORTHERN ITALY
}

\author{
D. Jovanović ${ }^{1 *}$, D. Oreni ${ }^{1}$ \\ ${ }^{1}$ Politecnico di Milano, Department of Architecture, Built environment and Construction Engineering, Italy \\ (dina.jovanovic, daniela.oreni)@polimi.it
}

KEY WORDS: widespread historical centres, northern Italy, urban analysis, historical data, historical cartography, GIS

\begin{abstract}
:
Researchers from diverse fields of study are developing methodologies for understanding historical cartography. Nonetheless, there is a lack of literature that explains the connection between the survey and the interactive use of historical cartography in preservation projects and urban planning. This study demonstrates the methods for the investigation of historical cartography to produce knowledge about the heritage of small widespread historical centres in northern Italy, which had a rich history, and for which many thematic maps were produced through time. The complexity of the area gives a fertile ground to collect, systematise and investigate historical sources. The methodology is developed to be flexible and adaptable to various widespread historical centres in the territory and it is divided into two parts: deconstructive and constructive approach. Whereas the former deals with the analysis of urban aspects on historical maps, the latter searches for the historical elements present nowadays. Combining those two methods in the Geographic Information Systems will produce a timeline and historical stratification of the transformation of cities. Once georeferenced and vectorised, historical maps are enriched with the information from written registers and other historical documents, as well as contemporary ones. The study aims to scrutinize and produce various categories of maps, to draw conclusions about the limits of the use of historical cartography and software used, and finally, to suggest how and where the future work could lead to the overall enhancement of heritage.
\end{abstract}

\section{INTRODUCTION}

The research aims to develop the methodology to systematise, present and use historical cartography to analyse and potentially enhance widespread historical centres in northern Italy. Collecting and processing selected data will show the potentials and limits of historical cartography and other historical documents to investigate heritage and collect knowledge to be used in preservation projects. The study will indicate steps for analysing small historical centres using both the contents of maps with different levels of detail and historical data aiming to convey historical values to support the understanding of widespread built heritage at the urban scale.

Historical cartography and documents are an important but often neglected part of cultural heritage. They are not just artefacts with artistic values, but a necessary source of information about the space in the past (Cazzani, Brumana, and Zerbi, 2019). Historical maps permit the assessment of spatial relationships of the past and their development through time to allow both quantitative and qualitative diachronic analysis (Piovan, 2019). To be able to use historical maps and other historical documents to comprehend the evolution of towns, a GIS ${ }^{1}$-based approach is employed, to create a timeline of transformation of the urban tissue (Knowles and Hillier, 2008). This approach will allow a better understanding of historical sources to a wide group of stakeholders since cultural heritage is directly connected to cultural identity (ICOMOS, 1996).

Knowledge about the complexity of the site of interest will generate more elaborated preservation and management plans for built heritage. Investigation of the historical and current maps will provide historical stratification and will allow the collection of widespread values of historical centres. Moreover, the study will evaluate the built heritage and demonstrate the use of archival documentation, especially historical maps. This research will help to perform detailed surveys, gain the knowledge for positive impact on preservation, and enhance lost or hidden values to be presented to the public through new communication tool (Cazzani, Brumana, and Zerbi. 2019). The instruments presented together with a methodological approach described in the study could be used as an educational tool and for touristic purposes but especially could serve as a ground knowledge for the professionals to make elaborated contextualised projects (Bianchi, 2006).

\subsection{Digitalization: Indicators and recommendations}

The study stresses the importance of the digitalisation of textual and imagery-like historical data. Recently, new technologies have allowed the possibility to digitalise, protect and distribute knowledge about cultural heritage. There are numerous guidelines and recommendations written for the purpose pf adequately collecting all tangible and intangible values that heritage carries.

The European Commission stated that one of the priorities is digitalising archival documents including historical cartography (European Commission, 2018). Supporting digitalisation through the "Europeana" project, a digital cultural platform, they are building a European network of resilient, accessible, and sustainable heritage sources (Europeana, 2019).

Following the standards and recommendations of the European Union for digitalisation, the Steering Committee of the Italian Digital Library² (i.e., Comitato Guida della Biblioteca Digitale

*Corresponding author

${ }^{1}$ Geographic Information System

${ }^{2}$ www.iccu.sbn.it/it/ 
Italiana) was tasked with identifying guidelines and policies for digitalisation of Italian cultural heritage (ICCU, 2006).

ICOMOS charter gave the indicators for conservation of historic towns and listed the qualities to be included in the survey such as the urban patterns, relationships between buildings, greenery and open spaces, the formal and informal appearances of buildings, change in the setting and function of an urban area, etc (ICOMOS, 1996). Furthermore, ICOMOS earlier recognised the importance of multidisciplinary studies that should be the backbone of every preservation project (ICOMOS, 1987).

\subsection{Positional importance}

In the Po Valley, there have been numerous changes in power throughout history. Starting with the antiquity period, the coming of Celtic Gallic tribes that were replaced by the arrival of the Roman empire, this geographical plain has transformed through time. During the Middle Ages, the medieval municipality was a new political model which repopulated the cities, but from the $13^{\text {th }}$ century was substituted by the lordship of influential families (Pini, 1986). From the $15^{\text {th }}$ century, battles broke out across the valley again, with the conquests of Venetians from the east and later of French and Spanish troops. Particularly, the Duchy of Milan in 1714 passed by inheritance from the Habsburgs of Spain to the Habsburgs of Austria, continuing the long-time occupation, until 1797 when Lombardy again united under the aegis of Napoleon Bonaparte. Milano has been on several occasions the capital of the realm due to its strategic position, being closer to the borders of other empires (Desmond, 2001). In 1815, Austrian rule was restored as the Lombardo-Venetian Kingdom until the unity in 1861 when Lombardy became part of the modern Italian state (Israel and Ortalli, 2011).

The intricacy of the area of interest is visible from the layers of history. Cities were under constant rebuild and destruction phases through time, affected by human and natural hazards, and often heritage suffered greatly. The presence of different reigns produced various thematic maps and cadastres, which gives the fertile ground for further research with all its complexity. Similarly, drawings and architectural representations, both at the urban scale and the scale of the single building, are often the only ones that were documented. They allow us to read the different stratifications that had occurred on diffuse, minor built heritage, often characterized by a rural character, highlighting its permanence and mutations. For many of these buildings, there is no large quantity of archival documents that permit the reconstruction of their historical evolution. Therefore, cadastral maps with the relative information contained in the registers are fundamental historical sources that are available to researchers.

Having historical sources coming from diverse periods can help in understanding the changes of widespread small heritage centres through centuries, especially in those which changed until the derecognition of the appearance of urban structure and built heritage in the industrial period, where their historical values are visible in traces or unperceived at all. Moreover, building and testing the methodology on different widespread centres inside the same territory can produce stronger ties among data for more elaborated surveys.

\section{RELATED WORK}

Previous works done about the area of interest are valuable sources of information because they offer the opportunity to continue the analysis in northern Italy by further developing the presented methodology and have insights into the limitations in data collection and processing.
"GeoPan Atl@s"3 is a project which is created in 2011. It is developed as a continuation of a series of activities previously conducted by researchers at Politecnico di Milano (e.g., Polytechnic University of Milan) in a collaboration with archives and other institutions. Through the WebGIS the user can consult modern data with historical cadastres and topographical maps of Lombardy from the $17^{\text {th }}$ to $20^{\text {th }}$ century. The project aimed to raise awareness for the protection of landscape and urban structure, providing layered information through centuries for general knowledge and professional use (Oreni et al. 2010). It is based on the use of digitized and georeferenced historical maps to provide information on the history of territories and places to different users. In particular, between 2003 and 2005, the study and the analysis of some minor historical centres located in the Municipality of Cantù (Como) and historical farmhouses present in the municipal territory was carried out; the aim was to provide the public administration with a tool to read the consistency of the historical heritage and its transformations over time, starting from the cross-reading of the georeferenced historical maps and in situ recognition of the material, constructive and morphological characteristics of the single catalogued buildings (Brumana, Achille and Oreni 2004).

Another related work is the WebGIS "Catasti Storici" , created by private company Archimedia in collaboration with various Italian public archives (Bianchi, 2006). The researchers gathered historical cartography from the $18^{\text {th }}$ until the $20^{\text {th }}$ century in Lombardy. They addressed different cadastres to the maps, linking them through GIS. The project offered the possibility of historical reconstruction of the area, providing various functions such as thematic maps based on diverse topics, stressing the importance of historical cadastres, which became one of the vital tools to study the changes of the territory.

The project "Eco-museum of Tramezzina" on lake Como demonstrated the methodology and the WebGIS system used to create a virtual museum of the area in a form of an exhibition to valorise the landscape, make multimedia data available via the web and give information about heritage to tourists and professionals. The study established the timeline of the zone, from medieval times until today. The project includes multiscale and multi-temporal maps with different thematic purposes (Brumana et al. 2015).

Historical cartography has many varied uses for the preservation of cultural heritage and great potential in gaining knowledge of the past. One of the studies demonstrating the potential of historical maps is a study of the historical "Wool Road" in the vicinity of Bergamo. The idea is to valorise the road and artefacts built next to it for possible revitalisation. New digital tools, including the WebGIS system and various databases and maps, allowed researchers to investigate the tangible and intangible values of the area through historical sources (Condoleo et al. 2018).

\section{AVAILABLE CARTOGRAPHY AND SOURCES}

Apropos the historical cartography of the Lombardy Region is concerned, there are different public, private and religious archives that preserve maps and drawings, at different scales of representation. Not all the cartographic patrimony has been digitized and made available online yet, but it is now possible to access most maps through the public State Archives. From the

${ }^{3}$ geoserver.atlas.polimi.it/examples/servlets/Geopan/D/web_AP P/index.html

${ }^{4}$ Historical Cadastres:

www.catastistorici.it/zsiGrp dHVy-wabmNyjQO67wB9K/ 
Italian web portal of land registers and historical cartography Territor $^{5}$, it is possible to access the cadastral and territorial maps kept in the State Archives of Milan, Venice, and Genoa, concerning the current Lombardy territory, which in the past was subdivided under different states. In the State Archives, it is possible to find mainly cadastral maps, at the scale of 1:2.000, with their registers: The $18^{\text {th }}$-century Teresian Cadastre, the $19^{\text {th }}$-century Lombardo-Veneto Cadastre and the Nuovo Catasto Terreni, including the various updates. The recent cadastral maps, at the scale of 1:2.000 and 1:1.000, are instead stored in the Land Agency of the Lombardy region, but they are not available online. Many other historical maps are collected in the State Archives, at various levels of details and information; they could be fundamental to integrate geographical and infrastructural data of the cadastral maps, in which the selection of the information contained derived from a precise selection of the information needed only for fiscal purposes.

At the regional and national levels, there are also some public cartographic web portals. Specifically for the Lombardy region there is Geoportale della Lombardia 6 that provides historical cartography and $20^{\text {th }}$-century orthophotos at the scales from $1: 10.000$ to $1: 100.000$. As far as other maps of the Lombardy territory are concerned, many private and religious archives preserve historical drawings and maps: among them, the Istituto Geografico Militare (e.g., Military Geographical Institute), which does not offer maps that are freely accessible online. Among the religious archives, the Archivi Storici Diocesani (e.g., Diocesan Historical Archives) are worth mentioning, especially with a series of maps attached to past "pastoral visits" and which represent an important source of documentation and drawings of the main buildings of religious property over time.

\section{METHODOLOGY}

Historical Geographic Information System (HGIS) manages large spatial-temporal data. It can represent the space through the past and analyse historical data, both raster and vector. The interdisciplinary system that combines methods of geographic science with historical research is becoming a tool for reconstructing historical events and it gives a wide range of possibilities to analyse historical maps (Schaffer and Levin, 2015). Integration of historical data and historical maps through a digital database in HGIS can contribute to the efficiency in tracking changes and managing built heritage (Brumana et al. 2010).

The methodology is built in a way that can be replicated in various case studies. Starting with the collection of historical sources which are available for the northern part of Italy, specifically for the Lombardy region, the focus is to gather maps with different scales, themes, and periods to construct the timeline of urban changes in widespread small historical centres. Selected maps were analysed concerning their specific contents, strictly related to the objective for which each map was made (i.e., fiscal, geographic, infrastructural). Additionally, other historical documents, such as land registers, plans and illustrations were collected and linked to the historical maps. Contemporary research was not neglected, and it had an important role in the survey. The proximity of case studies allowed the field investigation of heritage centres, collection of photographic material and knowledge of the citizens about their common goods. On the architectural scale, a valuable source of information was a catalogue of Lombardian Cultural Heritage ${ }^{7}$ (e.g., Lombardia Beni Culturali) called SIRBeC - Information System of Cultural Heritage of the Lombardy Region (e.g., Sistema Informativo dei Beni Culturali di Regione Lombardia). The catalogue is a collection of dossiers of cultural heritage and its present state.

At the national level, the SIGECweb ${ }^{8}$ and the General Catalogue of the Cultural Heritage ${ }^{9}$ of ICCD - Istituto Centrale per il Catalogo e la Documentazione (e.g., Central Institute for Catalogue and Documentation), created by the Italian Ministry of the Culture, allows the user to consult many catalogue cards of public buildings protected by national protection laws.

The methodological approach has two parts: Deconstructive and Constructive approaches. The former primarily deals with deconstructing historical maps on single elements to gain information about the past while the "constructive approach" performs contemporary surveys to create new maps which will demonstrate historical elements existing nowadays. Nevertheless, the study starts from the present time, to understand which buildings preserved their original shape through time (e.g., built elements that had less probability of change through time which does not include vegetation, landscape, and water bodies), and could be identified on historical maps so that they can be used as Ground Control Points (GCP) for georeferentiation. Georeferentiation of the historical maps, in the coordinate system of today, provides the context for comparisons and analysis (Brigante and Radicioni, 2014) (Figures 1 and 2).

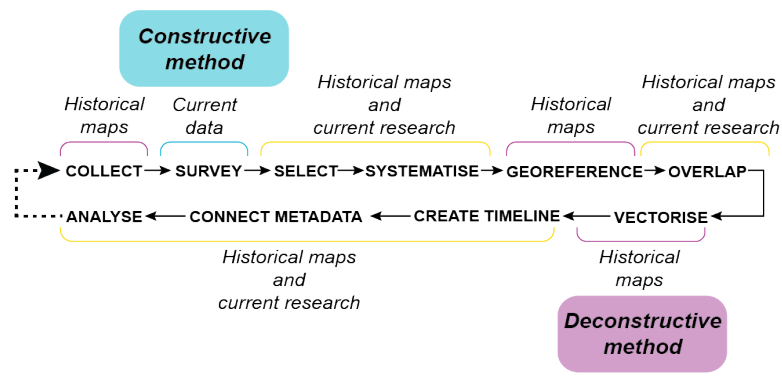

Figure 1. Methodological structure and steps undertaken to perform the study. Source: Authors

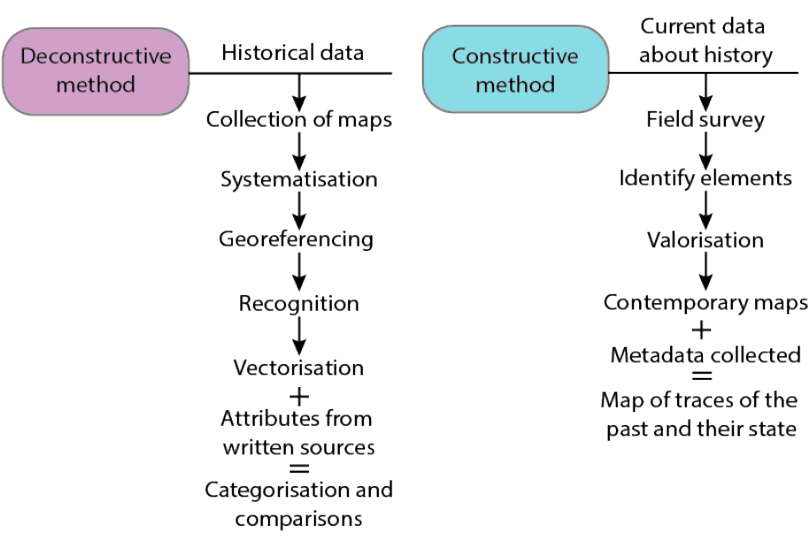

Figure 2. Structure of Constructive and Deconstructive methods (e.g., approaches). Source: Authors

\footnotetext{
${ }^{7}$ www.lombardiabeniculturali.it/architetture/

${ }^{8}$ www.sigecweb.beniculturali.it

${ }^{9}$ www.catalogo.beniculturali.it

${ }^{5} \mathrm{https} / / / \mathrm{www}$. icar.beniculturali.it/sistemi-e-portali/portalitematici/territori-il-portale-italiano-dei-catasti-e-dellacartografia-storica

${ }^{6} \mathrm{https}: / / \mathrm{www}$.geoportale.regione.lombardia.it
} 


\subsection{Data systematisation}

The first step of the research was consisted in the collection and selection of the available historical maps at different scale of representation, historical documents, and raw data. Georeferentiation was done before other research activities, to create layers of historical maps inside a GIS environment in the common coordinate system (Monti et al. 2009). When this step was finished, to perform the analysis and comparisons of the maps which are raster files, they needed to be vectorised so that they can contain other non-visual data. The study was focused on the buildings and parcels' division, and those elements were manually vectorised to serve as a container for other historical and contemporary information. Automatic vectorisation of historical maps still has not reached its perfection, especially on a bigger scale which require a better level of accuracy (Iosifescu, Tsorlini, and Hurni, 2016). Feasible for small historical centres, the authors recommended manual vectorisation of the maps, which can be controlled and will allow greater precision. The process of vectorisation of the maps was done using features in GIS: polygons, lines, and points.

\subsection{Deconstructive method}

The deconstructive method starts with the recognition of elements of the historical map that will be analysed, later vectorised, and connected with other historical documents which will describe them better. Polygons are created for the buildings, built and non-built parcels. Most of the documents, that are giving the third dimension to the maps, are written registers, which points out another challenge, how to represent textual data visually on the map. This can be overcome by creating metadata, or in other words, storing textual information in the attribute table of each referred polygon to perform further analysis. For the built parcels, information extracted from the land register to be stored in the attribute tables is about the owner of the property at that time, the function of the house, parcel number and belonging of the non-built parcels. Non-built parcels are divided into types (i.e., agricultural land, orchards, trees, meadows, parks, etc.) (Figure 3).

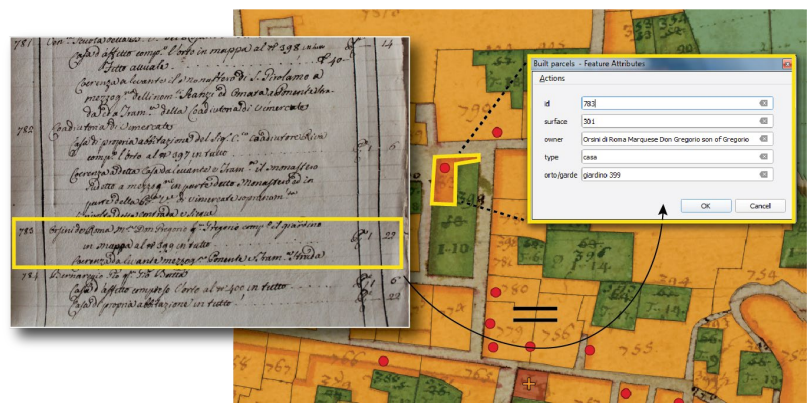

Figure 3. Connection of land register and map. Data are placed in the attribute tables of vector polygon features. Source: $\mathrm{ASMi}^{10}$, authors

Lines are presenting streets and borders (i.e., the hypothesis of the positions of ancient walls and roads). They hold the data about present and past names of the streets. In this way, historical names of the streets can demonstrate traces of the past and trigger further search of existent or lost heritage (e.g., past function or owner (Figure 4).

${ }^{10}$ Archivio di Stato di Milano - State Archive of Milan ttps://archiviodistatomilano.beniculturali.it

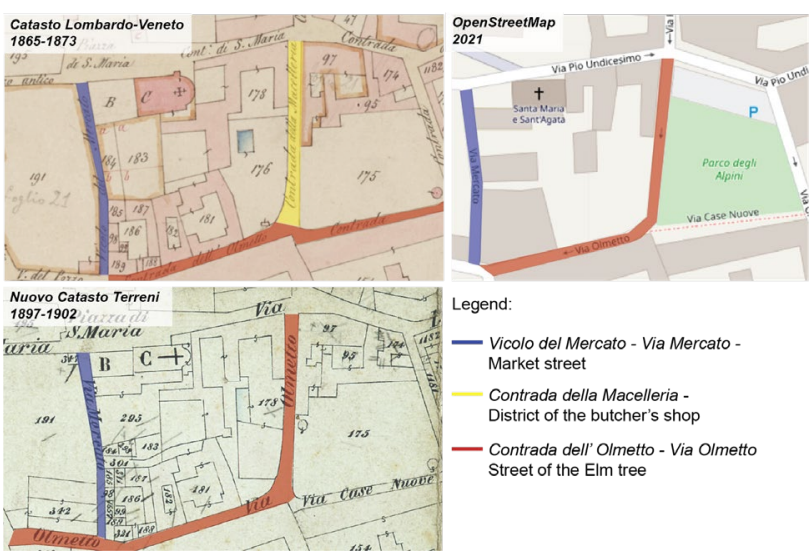

Figure 4. Example of streets' names in Desio and their change through time. The presence of different services and events, religious buildings or vegetation determined the name of a street (surface highlighted for better visualisation). Source: ASMi, OpenStreetMap, authors

\subsection{Constructive method}

The adequate foundation is created for future studies of heritage by vectorising the elements which will be investigated on historical maps. Although, there is a need for integrating these data with the present state of built heritage. Point features illustrate positions of existing built cultural heritage, and they store data from historical land registers and contemporary studies (i.e., style, architect, description, photo, etc.).

The part of this method consisted of collecting data about the town today and contemporary maps, evaluating the present state of the buildings, exploring the data about current owners, etc. Additionally, from the attribute table, there is direct access to the SIRBeC catalogue and students' projects done at the preservation courses (Figure 5).
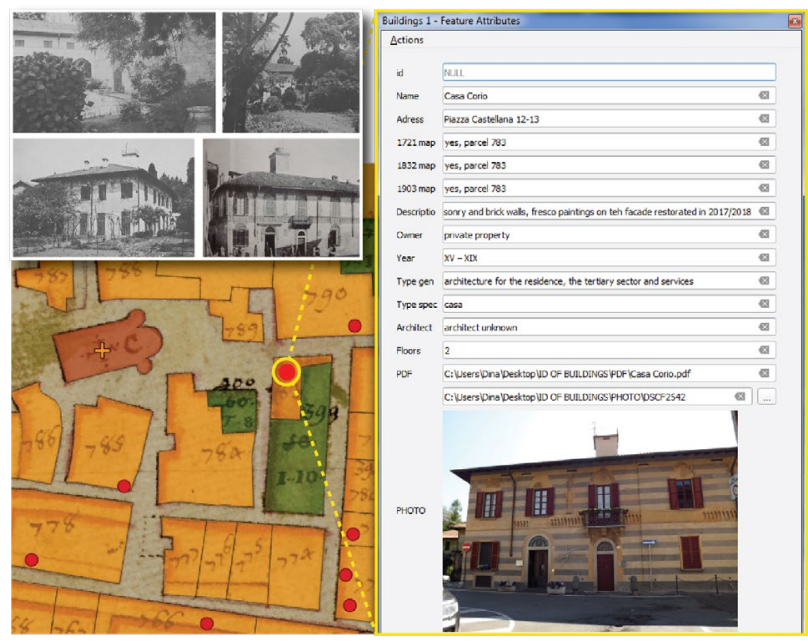

Figure 5. Point feature: A "container" with information about heritage that allows direct access to the SIRBeC documentation and other related projects. Source: ASMi, Beni Culturali Lombardia, Authors.

Another part of the "constructive method" is executed on the field, collecting the photographic material, memories of the citizens and looking into private archives. Constructing new maps which will present "traces of the past" inside the centre 
nowadays, required deep investigation of the town by foot. Elements that were specific for the past construction techniques can often indicate the function, originality, influences in the style of architecture, etc. Existence of following historical elements in the widespread historical centres were collected: presence of wooden truss roof construction typical for this area, architectural and decorative historical elements (i.e., columns, sills, inscriptions, gates, etc.), retained original shape of inner courtyards, type of façade decoration (i.e., affresco, graffiti, mural paintings, etc.) and state of maintenance of heritage buildings (Figure 6).

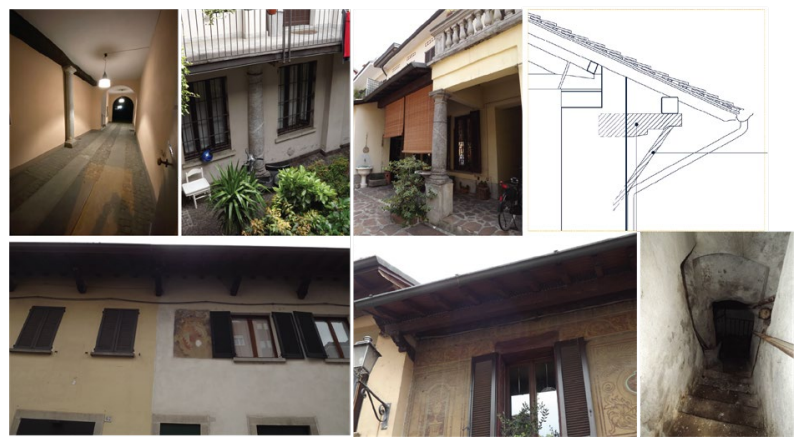

Figure 6. Photographic survey and technical drawings of found "traces of the past" in the historical centres. Source: Authors

\section{DATA PROCESSING IN GIS}

Modifications of buildings, streets and blocks through time are visible after comparison of maps. Vectorising them was the most effective way to proceed with the analysis. Urban transformation is readable when historical maps from different periods are layered inside one system. Collection and systematisation of data, historical and present, were done in GIS software. QGIS was used for this purpose: open and free software to appoint the importance of sharing information about heritage among all stakeholders (Figure 7).

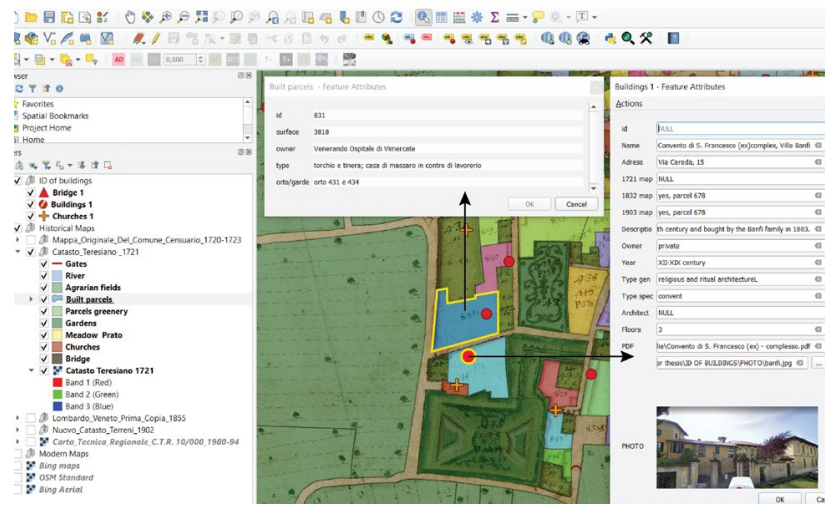

Figure 7. QGIS interface: Project visualisation. Layers' organisation and attribute tables of point and polygon features. Source: Authors

The "deconstructive method" allowed the analysis, visualisation of historical stratification of urban centre and extraction of elements to be investigated from historical maps so further surveys and conclusions can be made. Categorising the data stored in the attribute tables (e.g., past/present ownership, functions, gardens, agricultural fields, etc.) allowed clearer visualisation of the changes of ownership, what belonged in a certain period to prominent personalities, changes of the buildings' volumes and functions, streets' names, land use, etc.
The series of the maps drawn between 1721 and 1723 (primarily known as Charles VI's maps) called Mappa di attivazione del Catasto Teresiano - beni di prima stazione ${ }^{11}$ (1721) were the first set of maps investigated for this area. The focus of the maps was not on the buildings but on the division of built and non-built parcels for taxation and property management during the rule of Hapsburg empire. Drawn on the scale of 1:2000 in detail presents types of agrarian fields, arable lands, gardens and built parcels with additional written cadastral details on the side of the sheets (Figure 8). In different towns the level of representation of the buildings is diverse (i.e., in Desio buildings were drawn precisely, while in Vimercate were indicated the which are built parcels but not the exact shape of the building). Thirty years later, Catasto Teresiano - beni di seconda stazione ${ }^{12}$ (1757), and written land registers Comune Censuario $^{13}$ were made. The latter is useful for detailed data about the ownership, function of the houses and their sizes (Jovanović et al. 2021). Vectorisation of the map allowed placing this written information inside the attribute table so that categorizing them can produce various thematic maps.

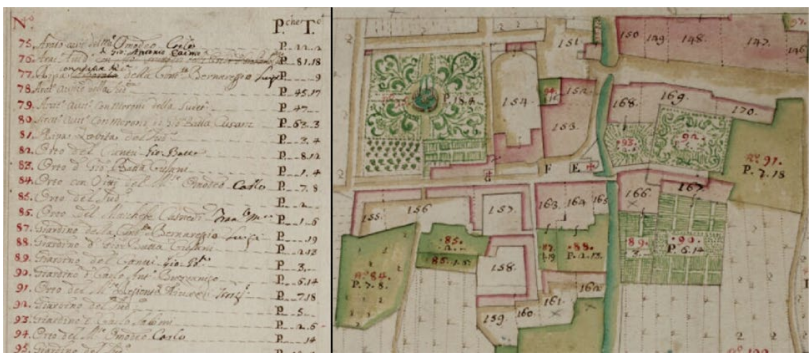

Figure 8. Map Catasto Teresiano (1721) in Cusano. Detailed representation of the purpose of non-built parcels on the right, and on the left land register data. Source: ASMi

The second set of maps used is Mappa Lombardo-Veneto, Nuovo Censo, Prima Copia ${ }^{14}$ produced from the 1850s and onwards, drawn on a scale of 1:2000, gave the detailed shape of the buildings but with much fewer details about non-built parcels. For the first time, the names of streets appear on the map. Specific to the map is that it highlights the water bodies (i.e., wells, pools, canals, etc.) (Figure 9). Overlapping with the map Catasto Teresiano, there is an evident sprawl and change in the urban structure in almost all widespread small centres. On an architectural scale, there are detectable modifications of buildings' functions.
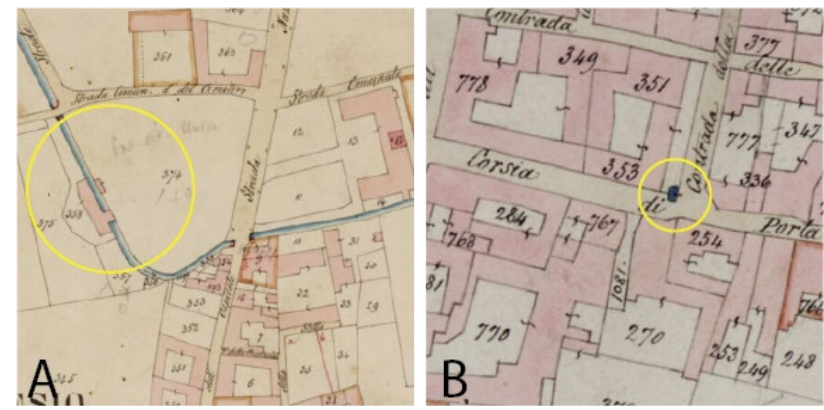

Figure 9. Maps of Cadastre Lombardo-Veneto, water elements highlighted in blue A) in Desio (canal) and B) Vimercate (well)

\footnotetext{
${ }^{11}$ Land cadastres of the first survey

12 Land cadastres of the second survey

${ }^{13}$ Municipality census

${ }^{14}$ The new survey, first copy
} 
The third set of maps layered inside one GIS project together with previously mentioned is Mappa Nuovo Catasto Terreni ${ }^{15}$ made between 1897 and 1902 on the scale of 1:2000. There is a noticeable spread on the outskirts of the cities mainly with the construction of entire settlements. Displacement of the building blocks and streets' organisation in the historical centre, upgrades, and volumes' changes, as well as conversions of the plots, are evident while overlapping historical maps (Figure 10).
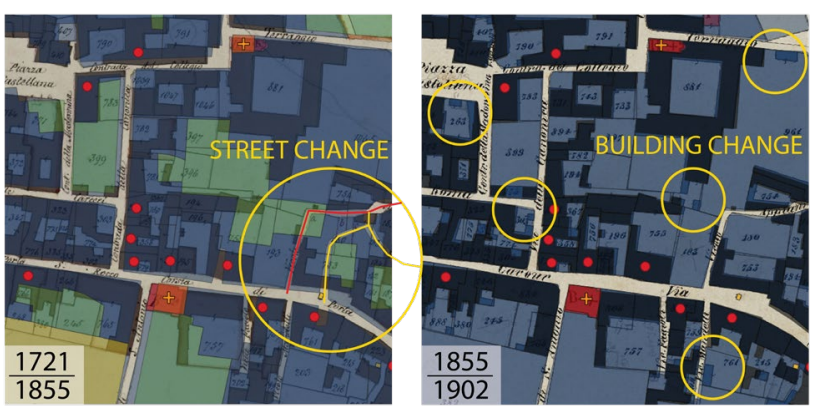

Figure 10. Comparison of historical maps. Changes in the streets' distribution and modification of buildings (enclosing an inner courtyard with service buildings). Source: ASMi, Authors

The "constructive method" follows the opposite process, searching for the traces of the historical elements in the present, and placing those data inside the GIS, to give insights into the overall state of heritage in the historical centre. New data collected are stored in the attribute tables of polygon features of vector files of contemporary map and can be easily categorised to produce diverse thematic maps or to access important documentation of surveys from third parties.

\section{RESULTS}

\subsection{Data visualisation}

Performing "deconstructive method" will allow different visualisations of changes throughout time of the historical centres and the creation of various thematic maps on an urban and an architectural scale. On an architectural scale, variations in the courtyard and building's planimetry also indicated some shifts in tendencies and trends of building Lombardian villa through time, starting as the U letter-shaped plan, villas were open to the street with the dual function of being living and working environments (i.e., usually for agricultural management). At the same time, inside villages, the main body of the villa tends to line up with the street or square in front, often interposing gates or service areas with a central hall passing through as an entrance to a close courtyard between public and private spaces. The 19th and the 20th century saw the rise of a fashion of constructing a villa surrounded by a vast garden on the periphery (Vv. Aa. 1997; Sacchi et al. 2007). In addition, the thematic maps produced can demonstrate the ownership in the past, horticulture changes, and functions of the buildings through time (Figure 11). On an urban scale, there is visible evolution of these widespread historical centres, development of infrastructure and sprawl, essentially at the beginning of the $20^{\text {th }}$ century and with the development of the industrial sector.

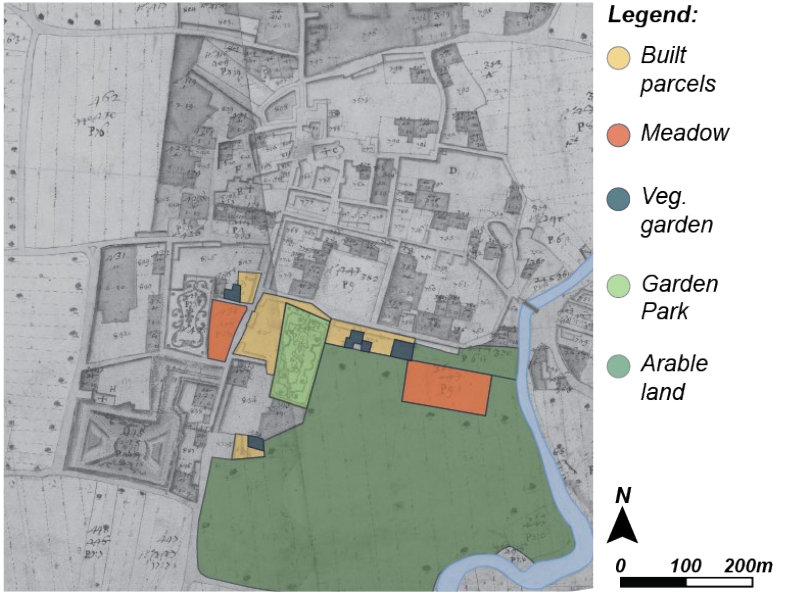

Figure 11. Map Catasto Teresiano (1721), the thematic map made by the categorisation by the owner Marquis Senator Goldone Vidone. Source: ASMi, authors

On the other hand, the "constructive method" will allow the creation of thematic maps of the presence of historical elements, or as previously called "traces of the past", integrated into the historical centre nowadays, that will indicate historical importance and authenticity (Figure 12). Some of the elements lost their primary purpose but they are left as a reminder of the past constructions (Figure 13). In addition, collecting material available in the present state of the town will give awareness of the state of the heritage, to indicate where the plan for maintenance and management needs to be conducted urgently. The contemporary studies will be valuable to following preservation projects and will create the framework for possible future work on these buildings, which can be also important for the municipalities and citizens.

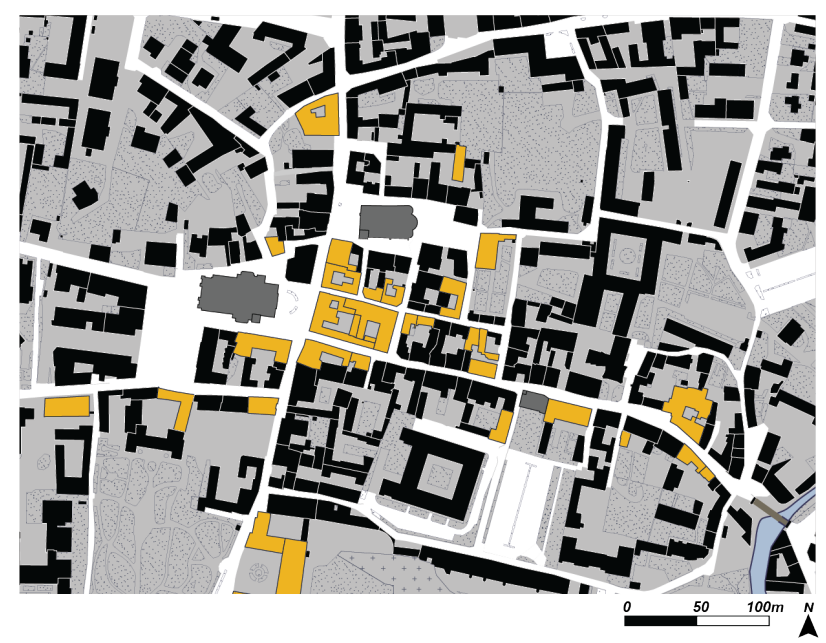

Figure 12. "Constructive approach": A map of the presence of basements (in yellow) in the historical centre today, can indicate the previous functions and construction period. Source: authors' survey

\footnotetext{
${ }^{15}$ New land cadastral map
} 


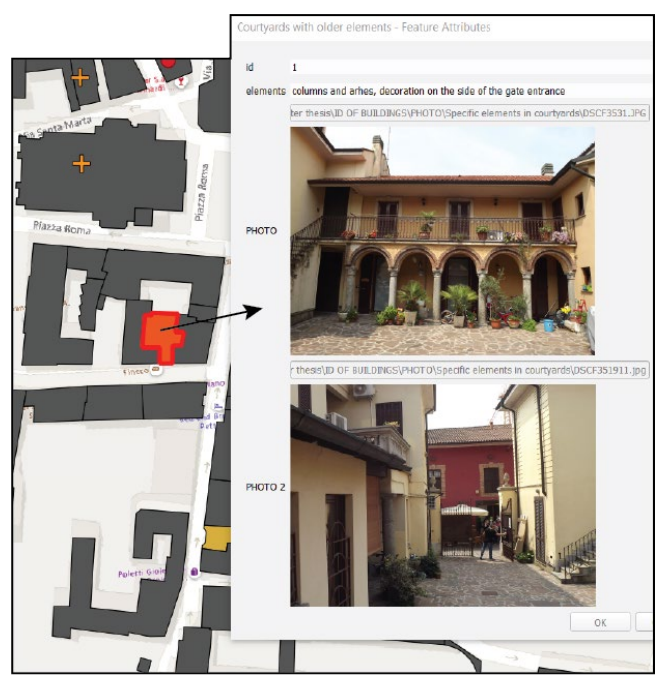

Figure 13. "Traces of the past" stored in the attribute table. Elements remained from the past in the present constructions. Source: Authors.

\subsection{Challenges and limits}

QGIS can store a large amount of data but its interface (i.e., layers panel) can create confusion and disintegration of data which makes it arduous to conduct consistent historical analysis. The GIS project can support more data by systematizing the historical timeline, and it will be useful adding other cadastres and maps on the territorial scale to create the continuity of the work and connect widespread historical centres on a smaller scale. In addition, there is a possibility for future development of vectorising other elements and get the complete image of changes of the city (i.e., land use, streets, natural elements, etc.). Another limitation can be manual vectorisation of historical maps, which can be precise but time consuming for bigger historical centres and more complex urban tissues. In future, the creation of WebGIS will allow better accessibility and will create an open and free knowledge platform about common goods.

There is a certain difficulty in surveying private buildings and often it is not possible to access all spaces. In this study, the maps presenting the "constructive method", specifically the one about the presence of the basement, the exact shape of the basement is not indicated, but the buildings which have basement are marked. This is because it was not possible to understand the dimensions of these spaces due to chock-ablock.

Some buildings, considered to be of value for the heritage, are not surveyed by Beni Culturali Lombardia, and there are no available SIRBeC documents. Most of the reports are considered outdated (made in the 1990s and early 2000s) and they need to be redone to get the real overall state of those buildings.

\section{CONCLUSION}

The researchers (e.g., historians, archaeologists, architects, etc.) are developing methodologies for understanding historical cartography but there is a lack of literature that explains the connection between the survey and the interactive use of historical cartography in preservation projects and urban planning. The study shows the methods for the investigation of historical cartography to produce the knowledge of the heritage of small historical centres as a foundation for other projects. The authors developed the timeline of the urban transformations and changes of the buildings that indicates diverse styles and aspirations in the construction trends in various periods. Moreover, conducting the project inside the GIS environment allowed many diverse spatial-temporal analysis, which resulted in the creation of thematic maps on different topics. The part of the research "deconstructive approach" resulted in layering the historical maps, vectorising them to be able to connect land registers' data, which allowed the visualisation of a text in a map. Vectorising single elements of interest, it was possible to track changes of the buildings or urban transformation. The second part, "the constructive approach" generated the information about the present state of widespread historical centres and historical elements that can be found nowadays.

The study of crucial importance for the elaborated preservation project and serves as a valuable groundwork for other architectural and urban planning projects. In addition, it stresses the significance of digitalisation of historical cartography and information that could be found in a historical document, presents the methodological approach to systematise and process collected data, and creates new material for future developments.

\section{REFERENCES}

Bianchi, A. 2006. "Una terra tra due fiumi. Il sistema informativo sul catasto Lombardo Veneto per 1'Isola Brembana." Insula, Anno II, Numero 2. 149-157

Brigante, R., Radicioni, F., 2014. "Georeferencing of Historical Maps: GIS Technology for Urban Analysis.” Geographia Technica 9 (1): 10-19.

Brumana R., Achille C., Oreni D., 2004. "Studio e raccolta di dati finalizzati all'analisi dei Centri Storici di Vighizzolo, Cascina Amata e dei nuclei di interesse storico ambientale esterni all'abitato di Cantù (CO)". Rivista dell'Agenzia del Territorio Vol. III: 55-90.

Brumana, R., Cuca, B., Oreni, D., Prandi, F., Scaioni, M., 2010. "Integration of Old Cadastral Maps into Up-to-Date Geodatabases for Urban Planning." The International Archives of the Photogrammetry, Remote Sensing and Spatial Information Sciences, ISPRS Archive, part 4-8-2-W9, "Core Spatial Databases - Updating, Maintenance and Services from Theory to Practice", Haifa, Israel, Vol. XXXVIII: 90-95.

Brumana, R., Santana Quintero, M., Barazzetti, L., Previtali, M., Banfi, F., Oreni, D., Roels, D., Roncoroni, F., 2015. "Towards a Virtual HUB Approach for Landscape Assessment and Multimedia Ecomuseum Using Multitemporal-Maps." The International Archives of the Photogrammetry, Remote Sensing and Spatial Information Sciences, 2015. 25th International CIPA Symposium 2015, 31 August - 04 September 2015, Taipei, Taiwan. Vol. XL-5/W7: 49-56. https://doi.org/10.5194/isprsarchives-XL-5-W7-49-2015.

Cazzani, A., Brumana, R., Zerbi, C.M., 2019. "The Georeferenced XIX Century Cartography: An Analysis Tool and a Project Reference for the Preservation and Management of Built and Landscape Heritage." The International Archives of the Photogrammetry, Remote Sensing \& Spatial Information Sciences, 2019. GEORES 2019- $2^{\text {nd }}$ International Conference of Geomatics and Restoration, 8-10 May 2019, Milan, Italy. Vol. XLII-a/W11: 395-402. https://doi.org/10.5194/isprs-archivesxlii-2-w11-395-2019 
Condoleo, P., Rolando, A., Oreni, D., Scandiffio, A., 2018. "The Rediscovery and Enhancement of the Historical 'Wool Road' through Its Recognition and Reuse Project." The "World Heritage and Knowledge" the XVI International Forum Le Vie dei Mercati, 14-16 June 2018, Napoli-Capri, Italy. 1220-29.

Desmond, G., 2001. Napoleon's Italy. Cranbury, N.J.: Fairleigh Dickinson University Press. 75-77.

European Commission. 2018. "Cultural Heritage: Digitalisation, online accessibility, and digital preservation. Consolidated Progress Report on the implementation of Commission Recommendation (2011/711/EU) 2015-2017”. European Commission, Directorate-General for communication networks, content and technology, Luxembourg. Accessed on 17.06.2021: www.digitalmeetsculture.net/wpcontent/uploads/2019/06/ReportonCulturalHeritageDigitisation OnlineAccessibilityandDigitalPreservation.pdf

Europeana. 2019. "Developing a common strategic approach for Member States to support the digital transformation of Europe's cultural heritage sector", Recommendations, September 2019, Netherlands, Accessed on 17.06.2021:

https://pro.europeana.eu/files/Europeana_Professional/Publicati ons/Final-Recommendations-for-a-Common-StrategicApproach.pdf

ICCU. 2006. Linee Guida per La Digitalizzazione Del Materiale Cartografico. Roma, Italia: Istituto centrale per il catalogo unico delle biblioteche italiane e per le informazioni bibliografiche. Accessed on 17.06.2021: www.iccu.sbn.it/export/sites/iccu/documenti/linee_guida_digit_ cartografia_05_2006.pdf

ICOMOS. 1996. "The Declaration of San Antonio". Accessed on 17.06.2021: www.icomos.org/en/charters-and-texts/179articles-en-francais/ressources/charters-and-standards/188-thedeclaration-of-san-antonio

ICOMOS. 1987. "Charter for the Conservation of Historic Towns and Urban Areas (Washington Charter, 1987)." Accessed on 17.06.2021:www.icomos.org/charters/towns_e.pdf

Iosifescu, I., Tsorlini, A., Hurni, L., 2016. "Towards a Comprehensive Methodology for Automatic Vectorization of Raster Historical Maps.” E-Perimetron Vol.11 (2): 57-76.

Israel, U., Ortalli, G., 2011. "Il Duello Fra Medioevo Ed Età Moderna: Prospettive Storico-Culturali." Il Duello Fra Medioevo Ed Età Moderna, 1-161.

Jovanović, D., Oreni, D., Della Torre, S., Moioli, R., 2021. "Analysis of historical cartography and data presentation for an educational purpose: The case of the historical centre of Vimercate. " Politecnico di Milano, 30th International Cartographic Conference, Florence, Italy, 14-18 December 2021 [Manuscript accepted for publication]

Knowles, A.K., Hillier, A., eds. 2008. Placing History: How Maps, Spatial Data, and GIS Are Changing Historical Scholarship, GIS and History. First edition. Redlands, California: ESRI, Inc. 2-6

Monti C., Achille C., Brumana R., Musumeci S., Oreni D., Signori M., 2009. ""Perspectives" on the 3-D analysis through the cadastral map series (XVIII - XX sec.) and the first geodetic large scale map of Milan realized by the 'Astronomi di Brera'
(Astronomers of Brera): toward an advanced portal". EPerimetron Vol. 4: 86-100.

Oreni, D., Brumana, R., Scaioni, M., Prandi, F., 2010. "Navigating on the Past, as a Bird Flight, in the Territorial Scale of Historical Topographic Maps. WMS on the 'Corografie Delle Province Del Regno Lombardo-Veneto', for Accessing Cadastral Map Catalogue.” E-Perimetron Vol.5 (4): 194-211.

Pini, A. I., 1986. Città, Comuni e Corporazioni Nel Medioevo Italiano. Vol. 1. Clueb.

Piovan, S., 2019. "Historical Maps in GIS." Geographic Information Science \& Technology Body of Knowledge 2019 (Q1). https://doi.org/10.22224/gistbok/2019.1.4.

Sacchi, F., Bianchini, F., Grieco, A., Cella, F., 2007. "Valorizzazione Delle Ville Gentilizie Dell'area Nord Milano." Regione Lombardia Beni Culturali - Direzione Generale Culture, Identità e Autonomie della Lombardia.

Schaffer, G., Levin, N., 2015. "Challenges and Possible Approaches for Using GIS as a Tool in Historical Geography Landscape Research: A Meta-Analysis Review." E-Perimetron Vol. 10 (3): 94-123.

Vv. Aa. 1997. La Villa Lombarda, Luogo Di Lavoro e Di Delizia. Zonta Club Milano I, La grafica Arlunese. 